\title{
Synthesis, Characterization and Antibacterial Studies on Mn(II) and Fe(II) Complexes of N, O Donor Salicyloyl Pyrazole Oxime Schiff Bases
}

\author{
NAMDEO T. DHOKALE¹, BHAUSAHEB K. KARALE² and ARVIND V. NAGAWADE ${ }^{1 *}$ \\ ${ }^{1}$ Department of Chemistry, Ahmednagar College, Ahmednagar (MS) India. \\ ${ }^{2}$ Department of Chemistry, Radhabai Kale Mahila Mahavidyalaya, Ahmednagar (MS) India. \\ ${ }^{*}$ Corresponding author E-mail: avnagawade@gmail.com \\ http://dx.doi.org/10.13005/ojc/330118
}

(Received: December 29, 2016; Accepted: January 29, 2017)

\begin{abstract}
$\mathrm{Mn}$ (II) and Fe(II) complexes with Schiff bases substituted salicyloyl pyrazole oximes were synthesized by the reaction of CFPHMP, FPHMP, DCFPHMP, CFPHMMP and BFPHMP (see introduction for definitions) with transition metal ion Manganese $\left(\mathrm{Mn}^{2+}\right)$ and Iron $\left(\mathrm{Fe}^{2+}\right)$. They were characterized by analytical and spectral methods. The elemental analysis data reveal that the Schiff base metal (II) complexes have 1:2 (M:L) stoichiometry. The molar conductivity data showed them to be non electrolytes. The Schiff bases are bidentate coordinating through the imine nitrogen and phenolic oxygen of salicyloyl pyrazole oximes. Based on analytical and spectral data, four-coordinate geometry is assigned for all complexes. The electronic absorption spectra suqqests the square planer geometry for the complexes. The ligand salicyloyl pyrazole oximes and their $\mathrm{Mn}$ (II) and $\mathrm{Fe}$ (II) complexes were screened against bacillus subtilis, Staphylococus aureus, actinomycetes and pseudomonas.
\end{abstract}

Keywords: Antibacterial, elemental analysis, transition metal complexes, square planer, electrolytes.

\section{INTRODUCTION}

Hydroxyoximes are special class of Schiff base ligands which contains hydroxyl group in addition to imine functionality. It is easy to make coordinate bond with bivalent metal through Oxygen atom of phenol by deprotonation and through Nitrogen atom of imine group. The oxime group also plays an important role to promote inter and intra molecular hydrogen bond, to stabilize metal- organic molecule framework and used in extractive metallurgy and separation of metal ions ${ }^{1-4}$. The chemistry of oxime metal complexes is interesting because of these species shows variety of reactivity modes. They have been widely studied in variety of biochemical $\left.\right|^{5,6}$ and analytical applications ${ }^{7,8}$.

The oxime group attached to the pyrazole ring is very good donor group because of its potential to facilitate different coordination modes. Also it is 
Well known that $\mathrm{N}$ atom of oxime group involve in bond formation with metal atom and $\mathrm{O}$ atom forms bridge between two organic molecules through hydrogen bond. A pyrazole oxime ligand contains two different bridging functions ${ }^{9-11}$. A number of pyrazole derivatives show biological activity as antipyretic ${ }^{12}$, antimicrobial ${ }^{13}$ and antitumor activity ${ }^{14}$. Pyrazole derivatives are also used in agriculture as pesticides ${ }^{15-16}$.

Fluorine substituted heterocyclic compounds and their analogues are accepted by enzymes as substrate because fluorine is comparable with steric demand to hydrogen. When fluorine attached to molecule it increases the activity of molecules. Fluorinated analogue of natural occurring nucleic acid are found to associate with various biological activity such as, antiviral ${ }^{17}$, antitumor ${ }^{18-19}$, antifungal ${ }^{20}$ and antimicrobial activity ${ }^{21}$. All literature survey suggest that, the transition metal containing pyrazole moiety and fluorine substituent has great importance in the field of chemistry and large applications in agriculture, industrial and biological studies.

In this present study we report synthesis and characterization of Manganese $\left(\mathrm{Mn}^{2+}\right)$ and Iron $\left(\mathrm{Fe}^{2+}\right)$ complexes with $\mathrm{N}$ and $\mathrm{O}$ donor Schiff bases, 4-chloro-2-[(E)-[1-(4-fluorophenyl)-1 H-pyrazol-4-yl] (hydroxyimino)methyl]phenol, (CFPHMP), 2-[(E)[1-(4-fluorophenyl)-1 H-pyrazol-4-yl](hydroxyimino) methyl]-4-methylphenol (FPHMP), 2,4-dichloro-6-[(E)[1-(4-fluorophenyl)-1 H-pyrazol-4-yl](hydroxyimino) methyl]phenol (DCFPHMP), 4-chloro-2-[(E)-[1-(4fluorophenyl)-1 H-pyrazol-4-yl](hydroxyimino)methyl]5-methylphenol (CFPHMMP) and 4-bromo-2-[(E)[1-(4-fluorophenyl)-1 H-pyrazol-4-yl](hydroxyimino) methyl]phenol (BFPHMP). The antibacterial activity of Schiff bases and their manganese $\left(\mathrm{Mn}^{2+}\right)$ and Iron $\left(\mathrm{Fe}^{2+}\right)$ complexes were tested against bacillus subtilis, Staphylococus aureus, actinomycetes and pseudomonas.

\section{MATERIAL AND METHODS}

Most of the chemicals used were analytical grade. The solvents were research grade and used after purification. $\mathrm{MnSO}_{4}$ and $\mathrm{FeSO}_{4}$ were used without purification. Both water and ethyl alcohol were distilled before use. The ligand salicyloyl pyrazole oxime was prepared using the method reported in our previous investigation ${ }^{22}$ Melting points of the complexes were determined in open glass capillaries and are uncorrected. The conductance of synthesized complexes was measured using $10^{-3} \mathrm{M}$ solution of complexes in DMF on Elico digital conductivity meter (Model CM-180). The elemental analysis was recorded on Thermo Scientific (FLASH 2000) elemental analyzer and the FTIR spectra were recorded in the range 4000$350 \mathrm{~cm}^{-1}$ on Shimadzu FTIR spectrophotometer. The thermal analysis was recorded on Shimadzu Thermometric Analyzer (TGA-50). UV-Visible spectra were recorded on Shimadzu UV-Visible double beam spectrophotometer. The percentages of metal ions in complexes were determined using standard volumetric methods ${ }^{23}$.

\section{Synthesis of Metal complexes}

Metal sulphate (One equivalent) was dissolved in distilled water and acidified by concentrated Hydrochloric acid. The resulting acidic solution was made warm using hot water bath. It was further treated with alcoholic ligand CFPHMP, FPHMP, DCFPHMP, CFPHMMP and BFPHMP solution (2 equivalents). The addition of ligand solution was made slowly drop after drop. Slight excess of ligand solution was added to ensure the complete Complexation. The resulting mixed solution was then treated with alcoholic ammonia to make it alkaline. The solution was then digested on boiling water bath where colored complex precipitated out. The product was filtered, washed first with little hot distilled water and then by ethyl alcohol to remove excess of ligand. It was dried under ambient conditions.

\section{RESULT AND DISCUSSIONS}

The Schiff base $\mathrm{Mn}$ (II) complexes (Ib-Vb) and Fe (II) complexes (Ic-Vc) were synthesized and characterized by various spectroscopic techniques. The synthesized compounds are non hygroscopic, stable solids insoluble in water and other solvents. All the complexes are soluble in DMF and DMSO. The analytical data and molar conductivity data of metal complexes are presented in table $1 \&$ table 2 . The elemental analysis data of the metal complexes are consistent with their general formulation $\mathrm{ML}_{2}$. The Mn (II) complexes are dark shiny brown in color where as Fe (II) complexes are brown in color. The 
colors of complexes are different from the color of ligand indicating that formation of color depends on type of metal ion. The melting points of complexes are different than that of ligand is an evidence for complexetion. The metal complexes were dissolved in DMF and the molar conductivities of their $10^{-3} \mathrm{M}$ solutions were measured at room temperature on conductivity meter. The low molar conductivity values of metal complexes suggest their non electrolytic nature ${ }^{24}$. The structures of the complexes were predicted based on analytical, spectroscopic and thermal measurements.

\section{IR spectra}

The FTIR spectra of metal complexes were recorded over the range $4000-350 \mathrm{~cm}^{-1}$. The most important bands in IR spectra of free ligand and its metal complexes are presented in table- 3 and table-4. To study the binding mode of ligand and metal, IR spectra of free ligand and corresponding metal complexes were compared. The important vibrational bands have been assigned on the basis of reported assignments ${ }^{25-26}$. The free ligand exhibit broad band in the $3391-3248 \mathrm{~cm}^{-1}$ range assignable to free $\mathrm{i}(\mathrm{O}-\mathrm{H})$ stretching frequency which is obviously absent in the spectra of metal complexes indicating deprotonation and involved in the formation of metal oxygen bond of phenolic group. The band in the $3166-3131 \mathrm{~cm}^{-1}$ range assignable to hydrogen bonded $v(\mathrm{O}-\mathrm{H})$ stretching frequency and shifting to lower frequency, indicative of the coordination of nitrogen atom and strong hydrogen bonding. Evidence for this coordination also arise from the small shift towards lower frequency of the band in the 1563-1542 $\mathrm{cm}^{-1}$ range assigned to $v(\mathrm{C}=\mathrm{N})$ stretching and $v(\mathrm{~N}-\mathrm{O})$ stretching in the $1282-1226 \mathrm{~cm}^{-1}$ range. The absorption peaks due to $v(\mathrm{C}-\mathrm{O})$ observed in the $1097-1073 \mathrm{~cm}^{-1}$ region. The spectra of free ligand moved towards low frequency in the spectra of the complexes. This supports bonding of the metal ions to the phenolic $\mathrm{OH}$ after deprotonation ${ }^{27-28}$. The oxygen and nitrogen coordination to the metal ion is proved by the bands that appears in the range $557-540 \mathrm{~cm}-1$ and $464-447 \mathrm{~cm}-1$ assigned to $v(\mathrm{M}-\mathrm{O})$ and $v(\mathrm{M}-\mathrm{N})$ respectively ${ }^{29-30}$.

\section{Thermal Analysis}

Thermal behaviors of complexes have been studied using TGA in air as atmosphere. Thermogravimetric analysis of metal complexes<smiles>[R]c1cc(C(=NO)c2cnn(-c3ccc(F)cc3)c2)c(O)c([R3])c1[R4]</smiles>

Schiff base (Ia-Va)

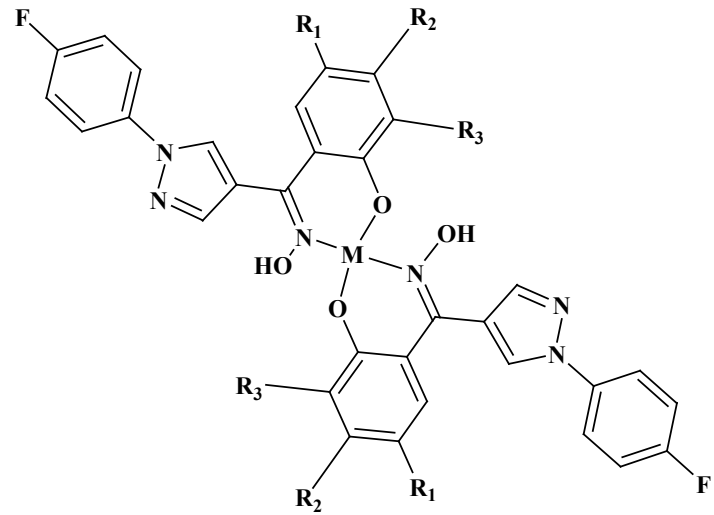

$\mathrm{Mn}(\mathrm{II})$ complexes (Ib-Vb) $\mathrm{Fe}$ (II) complexes (Ic-Vc)

\begin{tabular}{lccc} 
Compound & $\mathbf{R}_{\mathbf{1}}$ & $\mathbf{R}_{\mathbf{2}}$ & $\mathbf{R}_{\mathbf{3}}$ \\
\hline Ia, Ib, Ic & $\mathrm{Cl}$ & $\mathrm{H}$ & $\mathrm{H}$ \\
Ila, IIb, Ilc & $\mathrm{CH}_{3}$ & $\mathrm{H}$ & $\mathrm{H}$ \\
IIIA, IIIb, IIIc & $\mathrm{Cl}$ & $\mathrm{H}$ & $\mathrm{Cl}$ \\
IVa, IVb, IVc & $\mathrm{Cl}$ & $\mathrm{CH}_{3}$ & $\mathrm{H}$ \\
$\mathrm{Va}, \mathrm{Vb}, \mathrm{Vc}$ & $\mathrm{Br}$ & $\mathrm{H}$ & $\mathrm{H}$ \\
\hline
\end{tabular}

Scheme 1: Structures of Schiff bases and their Mn (II) and Fe (II) complexes 
was carried out from $30^{\circ} \mathrm{C}$ to $900^{\circ} \mathrm{C}$ at heating rate of $10^{\circ} \mathrm{C}$ per minutes. All the complexes investigated shows similar behavior in their thermograms. According to Thermogravimetric data of manganese and iron complexes exhibit high stability and melt with decomposition in the range $200-280^{\circ} \mathrm{C}$. In TGA thermograms of complexes does not show any significant weight loss up to $200^{\circ} \mathrm{C}$ indicating there is no lattice or coordinated water molecules. Like most of the organic metal complexes Mn (II) and Fe (II) complexes of salicyloyl pyrazole oxime decompose by producing fine powder. During decomposition gaseous products such as $\mathrm{CO}_{2}, \mathrm{NH}_{3}$ etc. formed as a result of fragmentation of ligand. Further increase in temperature, the complexes decompose slowly involving loss of ligand in the temperature range $600-850{ }^{\circ} \mathrm{C}$ leading to formation of air stable metal oxide as the end product.

\section{Electronic spectra}

The electronic spectra in ultra violet and visible region of selected ligands and their complexes were recorded. The solution of known concentration $\left(1 \times 10^{-4} \mathrm{M}\right)$ of ligands and its corresponding complexes prepared in DMF and their UV-Visible spectra were recorded in the region $190-700 \mathrm{~nm}$. The ligand shows absorption band at $300-350 \mathrm{~nm}$ is assigned to $\pi \rightarrow \pi^{*}$ of the aromatic chromophore. In addition to the band observe in the range 273-290 $\mathrm{nm}$ can be attributed to $\pi \rightarrow \pi^{*}$ transitions. In metal complexes exhibits two bands in the region 20,704 $-17,271 \mathrm{~cm}^{-1}$ and $15,924-15,948 \mathrm{~cm}^{-1}$ ) attributed to $d \rightarrow d$ transitions. This is probable indicative of four coordinate square planer geometry ${ }^{31}$.
${ }^{1} \mathrm{H}$ NMR spectra of all synthesized complexes recorded in DMSO as solvent and TMS as internal standard. However due to presence of metal ion, proton resonance was not effected and gave broad peaks indicating the formation of metal complexes.

XRD pattern of metal complexes were obtained in solid form. The X-ray diffractogram of all complexes showed broad peak, which indicate Polycrystalline nature ${ }^{32}$. Though amorphous nature of complexes was observed they were generally not soluble in non polar solvents.

\section{Biological Activity}

The antibacterial activity of salicyloyl pyrazole oxime and their metal complexes were screened against bacillus subtilis, Staphylococus aureus, actinomycetes and pseudomonas by the well diffusion method ${ }^{34}$. The test solutions were prepared in DMF, nutrient agar was used as culture medium. The zone of inhibition was measured in $\mathrm{mm}$ and presented table-5. All compounds were dissolved in DMF at $100 \mu \mathrm{g} / \mathrm{ml}$. DMF was used as solvent and also for control. The result showed that the complex IIIa had highest effect and la, IVb lowest effect against B. Subtilis than all other compounds. The metal complexes had higher antibacterial activity than free ligands against $S$. Aureus. Also in Actinomycetes the metal complexes had higher activity than free ligands except complex IIla, IIIb and Vb while the complex Ib showed highest antibacterial activity. All the free ligands and their Mn (II) and Fe (II) complexes showed similar activity against Pseudomonas. The

Table 1: Physical, Analytical and molar conductance of Mn (II) complexes

\begin{tabular}{|c|c|c|c|c|c|c|c|}
\hline \multirow[t]{2}{*}{ Complex } & \multirow[t]{2}{*}{ M. P. $\left({ }^{\circ} \mathrm{C}\right)$} & \multirow[t]{2}{*}{$\%$ Yield } & \multirow[b]{2}{*}{ M } & \multicolumn{3}{|c|}{ Found (Calcd.) \% } & \multirow[t]{2}{*}{$\Pi_{\mathrm{M}}$} \\
\hline & & & & C & $\mathbf{H}$ & $\mathbf{N}$ & \\
\hline $\operatorname{Mn}(\mathrm{CFPHMP})_{2}(\mathrm{Ib})$ & $>300$ & 90 & $\begin{array}{c}7.49 \\
(7.67)\end{array}$ & $\begin{array}{c}54.04 \\
(53.65)\end{array}$ & $\begin{array}{c}3.11 \\
(2.81)\end{array}$ & $\begin{array}{c}11.98 \\
(11.75)\end{array}$ & 17.3 \\
\hline $\mathrm{Mn}(\mathrm{FPHMP})_{2}(\mathrm{Ilb})$ & $224-226$ & 82 & $\begin{array}{c}7.97 \\
(8.13)\end{array}$ & $\begin{array}{c}60.03 \\
(60.45)\end{array}$ & $\begin{array}{c}3.46 \\
(3.88)\end{array}$ & $\begin{array}{c}12.61 \\
(12.44)\end{array}$ & 12.1 \\
\hline $\operatorname{Mn}(\mathrm{DCFPHMP})_{2}(\mathrm{IIlb})$ & $288-290$ & 74 & $\begin{array}{l}6.28 \\
(7.0)\end{array}$ & $\begin{array}{c}48.41 \\
(48.94)\end{array}$ & $\begin{array}{c}2.65 \\
(2.31)\end{array}$ & $\begin{array}{c}10.51 \\
(10.70)\end{array}$ & 17.3 \\
\hline $\mathrm{Mn}(\mathrm{CFPHMMP})_{2}(\mathrm{IVb})$ & $202-204$ & 82 & $\begin{array}{c}7.97 \\
(7.38)\end{array}$ & $\begin{array}{c}54.61 \\
(54.86)\end{array}$ & $\begin{array}{c}3.59 \\
(3.25)\end{array}$ & $\begin{array}{c}11.01 \\
(11.29)\end{array}$ & 19.9 \\
\hline Mn(BFPHMP)2 (Vb) & $212-214$ & 76 & $\begin{array}{c}6.76 \\
(6.82)\end{array}$ & $\begin{array}{c}47.57 \\
(47.73)\end{array}$ & $\begin{array}{c}2.94 \\
(2.50)\end{array}$ & $\begin{array}{c}10.22 \\
(10.44)\end{array}$ & 35.4 \\
\hline
\end{tabular}


dissimilarity in the activity of the different metal complexes against different bacteria depends either on the impermeability of the cells of the microbes or difference in the ribosomes in the microbial cells $35-36$

\section{CONCLUSION}

The experimental data suggests that prepared salicyloyl pyrazole oxime ligands posses two coordination sites. The physical and spectroscopic characterization of the complex reveled that oxygen

Table 2: Physical, Analytical and molar conductance of Fe (II) complexes

\begin{tabular}{|c|c|c|c|c|c|c|c|}
\hline \multirow[t]{2}{*}{ Complex } & \multirow[t]{2}{*}{ M. P. $\left({ }^{\circ} \mathrm{C}\right)$} & \multirow[t]{2}{*}{$\%$ Yield } & \multirow[b]{2}{*}{ M } & \multicolumn{3}{|c|}{ Found (Calcd.) \% } & \multirow[t]{2}{*}{$\Pi_{\mathrm{M}}$} \\
\hline & & & & C & $\mathbf{H}$ & $\mathbf{N}$ & \\
\hline $\mathrm{Fe}(\mathrm{CFPHMP})_{2}$ (Ic) & $>300$ & 93 & $\begin{array}{c}7.07 \\
(7.79)\end{array}$ & $\begin{array}{c}53.88 \\
(53.58)\end{array}$ & $\begin{array}{c}2.71 \\
(2.81)\end{array}$ & $\begin{array}{c}11.54 \\
(11.72)\end{array}$ & 60.6 \\
\hline $\mathrm{Fe}(\mathrm{FPHMP})_{2}(\mathrm{Ilc})$ & $280-282$ & 77 & $\begin{array}{c}8.93 \\
(8.26)\end{array}$ & $\begin{array}{c}60.11 \\
(60.37)\end{array}$ & $\begin{array}{c}3.99 \\
(3.87)\end{array}$ & $\begin{array}{c}12.86 \\
(12.42)\end{array}$ & 26.5 \\
\hline $\mathrm{Fe}(\mathrm{DCFPHMP})_{2}(\mathrm{IIIC})$ & $222-224$ & 75 & $\begin{array}{c}7.44 \\
(7.10)\end{array}$ & $\begin{array}{c}48.51 \\
(48.89)\end{array}$ & $\begin{array}{c}2.70 \\
(2.31)\end{array}$ & $\begin{array}{c}10.47 \\
(10.69)\end{array}$ & 33.3 \\
\hline $\mathrm{Fe}(\mathrm{CFPHMMP})_{2}(\mathrm{IVC})$ & $224-226$ & 65 & $\begin{array}{c}7.89 \\
(7.49)\end{array}$ & $\begin{array}{c}54.34 \\
(54.79)\end{array}$ & $\begin{array}{c}3.55 \\
(3.25)\end{array}$ & $\begin{array}{c}10.93 \\
(11.28)\end{array}$ & 33.6 \\
\hline $\mathrm{Fe}(\mathrm{BFPHMP})_{2}(\mathrm{Vc})$ & $234-236$ & 70 & $\begin{array}{c}7.14 \\
(6.93)\end{array}$ & $\begin{array}{c}47.91 \\
(47.67)\end{array}$ & $\begin{array}{c}2.86 \\
(2.50)\end{array}$ & $\begin{array}{c}10.23 \\
(10.42)\end{array}$ & 32.5 \\
\hline
\end{tabular}

Table 3: The significant peaks in FTIR spectra of free ligand and its $\mathrm{Mn}(\mathrm{II})$ complexes

\begin{tabular}{|c|c|c|c|c|c|c|c|c|c|c|c|c|}
\hline \multirow[t]{2}{*}{ Comp. } & \multicolumn{2}{|c|}{$v_{\mathrm{O}-\mathrm{H}}$} & \multicolumn{2}{|c|}{$v_{\mathrm{C}=\mathrm{N}}$} & \multicolumn{2}{|c|}{$v_{\mathrm{N}-\mathrm{O}}$} & \multicolumn{2}{|c|}{$v_{c-o}$} & \multicolumn{2}{|c|}{$v_{M-0}$} & \multicolumn{2}{|c|}{$v_{M-N}$} \\
\hline & $\mathbf{a}$ & b & a & b & $\mathbf{a}$ & b & a & b & a & b & a & b \\
\hline I & 3391,3131 & 3165 & 1563 & 1541 & 1232 & 1232 & 1097 & 1053 & - & 540 & - & 464 \\
\hline II & 3350,3134 & 3169 & 1542 & 1544 & 1231 & 1247 & 1097 & 1095 & - & 549 & - & 462 \\
\hline III & 3310,3166 & 3161 & 1545 & 1539 & 1242 & 1230 & 1088 & 1083 & - & 545 & - & 451 \\
\hline IV & 3327,3157 & 3153 & 1548 & 1543 & 1226 & 1230 & 1093 & 1097 & - & 553 & - & 457 \\
\hline V & 3248,3163 & 3142 & 1546 & 1537 & 1282 & 1230 & 1073 & 1097 & - & 555 & - & 460 \\
\hline
\end{tabular}

Table 4: The significant peaks in FTIR spectra of free ligand and its $\mathrm{Fe}(\mathrm{II})$ complexes

\begin{tabular}{|c|c|c|c|c|c|c|c|c|c|c|c|c|}
\hline \multirow[t]{2}{*}{ Comp. } & \multicolumn{2}{|c|}{$v_{\mathrm{O}-\mathrm{H}}$} & \multicolumn{2}{|c|}{$v_{C=N}$} & \multicolumn{2}{|c|}{$v_{\mathrm{N}-\mathrm{O}}$} & \multicolumn{2}{|c|}{$v_{c-0}$} & \multicolumn{2}{|c|}{$v_{M-O}$} & \multicolumn{2}{|c|}{$v_{M-N}$} \\
\hline & a & C & a & C & $\mathbf{a}$ & C & a & C & $a$ & C & $\mathbf{a}$ & C \\
\hline I & 3391,3131 & 3162 & 1563 & 1545 & 1232 & 1233 & 1097 & 1057 & - & 546 & - & 461 \\
\hline II & 3350,3134 & 3147 & 1542 & 1543 & 1231 & 1228 & 1097 & 1095 & - & 549 & - & 455 \\
\hline III & 3310,3166 & 3130 & 1545 & 1539 & 1242 & 1228 & 1088 & 1082 & - & 551 & - & 447 \\
\hline IV & 3327,3157 & 3138 & 1548 & 1539 & 1226 & 1230 & 1093 & 1095 & - & 557 & - & 459 \\
\hline $\mathrm{V}$ & 3248,3163 & 3157 & 1546 & 1539 & 1282 & 1230 & 1073 & 1095 & - & 553 & - & 447 \\
\hline
\end{tabular}




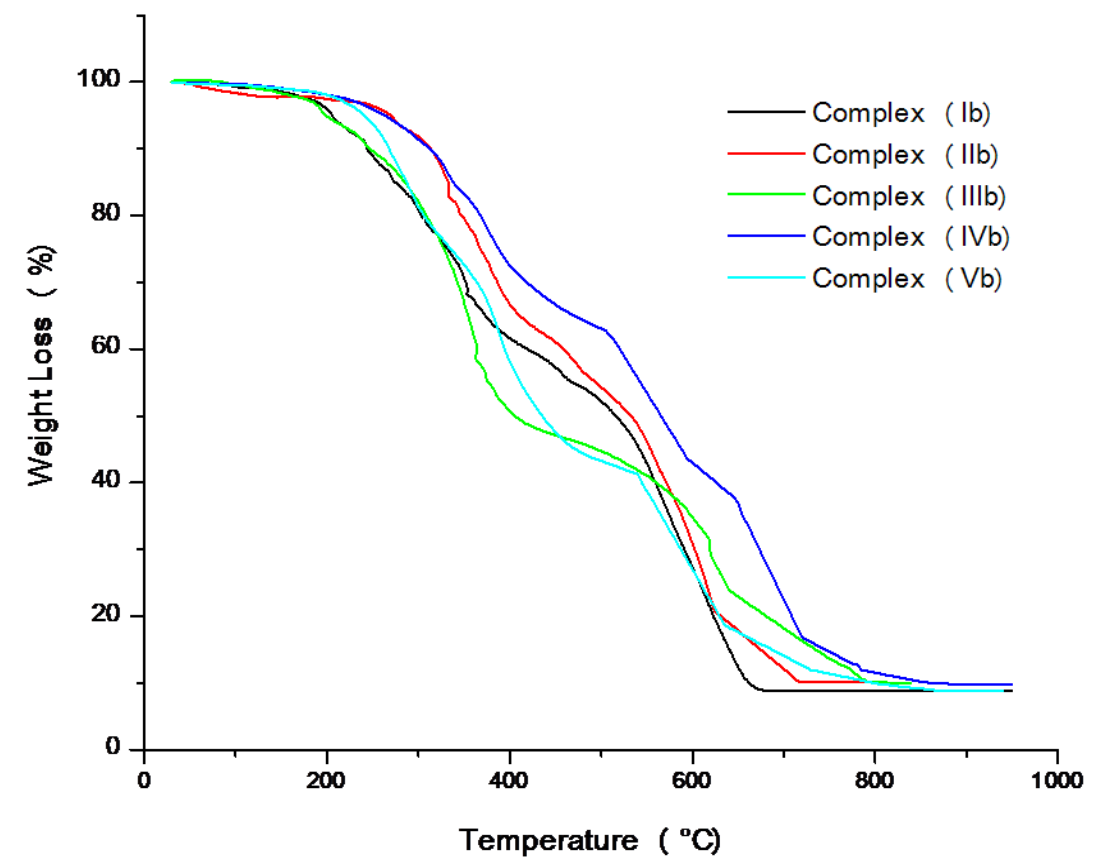

Fig. 1: TG spectra of Mn(II)complexes lb, Ilb, IIIb, IVb and Vb

Table 5: Antibacterial effect of free ligands and their Mn (II) and Fe (II) complexes

\begin{tabular}{llccc}
\hline Compound & \multicolumn{3}{c}{ Zone of inhibition in mm } \\
& B. Subtilis & S. Aureus & Actinomycetes & Pseudomonas \\
\hline I & 19 & 12 & 13 & 22 \\
II & 18 & 15 & 17 & 25 \\
III & 16 & 17 & 14 & 27 \\
IV & 18 & 16 & 16 & 31 \\
V & 18 & 12 & 17 & 23 \\
Ia & 12 & 15 & 24 & 26 \\
Ila & 16 & 18 & 23 & 24 \\
IIIa & 26 & 20 & 14 & 21 \\
IVa & 15 & 18 & 18 & 28 \\
Va & 14 & 21 & 17 & 30 \\
Ib & 17 & 15 & 28 & 25 \\
IIb & 15 & 23 & 19 & 28 \\
IIIb & 18 & 24 & 12 & 26 \\
IVb & 12 & 19 & 17 & 29 \\
Vb & 16 & 19 & 15 & 20 \\
Control & 08 & 10 & 10 & \\
\hline
\end{tabular}




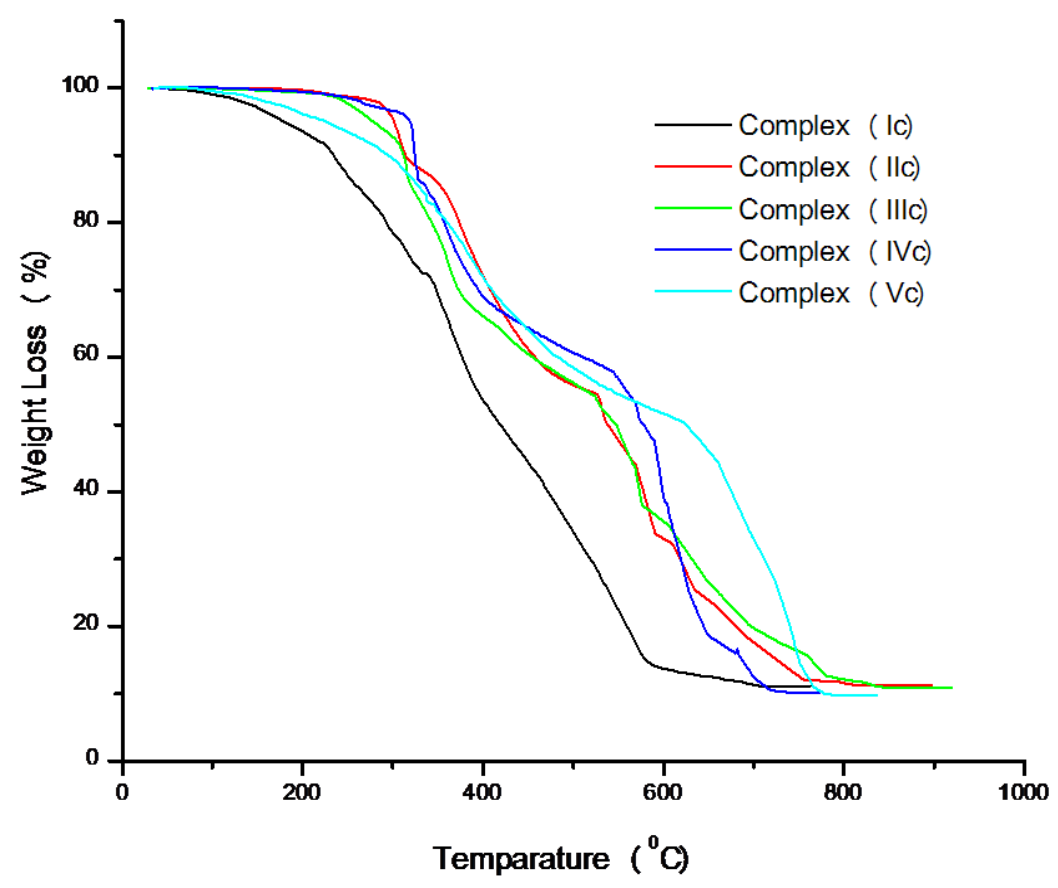

Fig. 2: TG spectra of Fe(II)complexes Ic, Ilc, IIIc, IVc and Vc

atom of phenol group and nitrogen atom of oxime group are involved in the coordination with the metal ion. The elemental analysis data suggest that the Schiff base metal (II) complexes have general formula $\mathrm{ML}_{2}$, Where $\mathrm{M}$ is $\mathrm{Mn}$ (II) and Fe (II). The complexes have good solubility in DMF and DMSO but were found to be insoluble in water and other organic solvents. The thermal analysis data suggested that complexes have high stability below $200^{\circ} \mathrm{C}$ and decomposes slowly after $200^{\circ} \mathrm{C}$ giving formation of corresponding metal oxides. The electronic absorption spectra reveled probably square planer geometry for the complexes. The magnitudes of molar conductance of these complexes suggested that complexes are non electrolytic in nature. The antibacterial data reveled that ligand and their metal complexes show considerable antimicrobial activity. However, the zone of inhibition of ligand varies with organisms as wel as metal ions. Thus it can be concluded that most of the ligands metal complexes posses moderate antimicrobial activity.

\section{ACKNOWLEDGMENT}

Authors are thankful to SAIF, Punjab University, Chandigarh and Department of Microbiology, K. J. Somaiya College, Kopargaon for providing antimicrobial activity.

\section{REFERENCES}

1. Chaudhari, P. Coord. Chem. Rev. 2003, 243 (1-2), 143-190.

2. Dong, W. K.; Feng, J. H.; Yang, X. Q. Synth. React. Org. Nano-Chem. 2007, 37 (3), 189192.

3. Dong, W. K.; Li, L.; Li, C. F.; Xu, L.; Duan, J. G. Spectrochim, Part-A 2008, 71(2), 650-654.
4. Sastre, A. M.; Szymanowski, J. J. Solvent.. Ion Exch. 2004, 22 (5), 737-759.

5. Luo, C.; Tong, M.; Maxwell, D. M.; Saxena, A. Chem-Biol, Interact. 2008, 175(1-3), 261266.

6. Naur, P.; Petersen, B. L.; Mikkelsen, M. D.; Bak, S.; Rasmussen, H.; Olsen, C. E.; Halkier, 
B. A. Plant, Physio. 2003, 133, 63-72.

7. Gergely, A.; Gyimesi-Forras, K.; Horvath, P.; Hosztafi, S.; Kokosi, J.; Nagy, P. I.; Szasz, G.; Szentesi, A. Curr. Med. Chem. 2004, 11(19), 2555-2564.

8. Urbansky, E. T.; Freeman D. M.; Elovitz, M. S. Water Res. 2000, 34 (9), 2610-2613.

9. Nanda, P. K.; Ray, D. Inorg Chim.Acta. 2005, 358 (13), 4039-4044.

10. Milios, C. J.; Kyritsis, P.; Raptopoulou, C. P.; Terzis, A.; Vicente, R.; Escuer A.; Perlepes, S. P. Dalton Trans 2005, 3, 501-511.

11. Zhan, S.; Hu, C.; Chen, X.; Meng, Q.; Lu, C.; Wang G.; Zheng, P. Polyhedron 1999, 18(11), 2035-2039.

12. Ivanenkov, Y. A.; Balakin, K. V.; Tkachenko, S. E. Drugs in R, 2008, 9 (6), 397-434.

13. Almeida da Silva, P. E.; Ramos, D. F.; Bonacorso, H. G.; de la Iglesia, A. I.; Oliveira, M. R.; Coelho, T.; Navarini, J.; Morbidoni, H. R.; Zanatta, N.; Martins, M. A. P. Int. J. Agents 2008, 32 (2), 139-144.

14. Reisner, E.; Arion, V. B.; Keppler B. K.; Pombeiro, A. J. L. Inorg Chim.Acta. 2008, 361 (6), 1569-1583.

15. Lemaire, G.; Mnif, W.; Pascussi, J. M.; Pillon, A.; Rabenoelina, F.; Fenet, H.; Gomez, E.; Casellas, C.; Nicolas, J. C.; Cavailles, V.; Duchesne, M. J.; Balaguer, P. Tox Sci. 2006, 91 (2), 501-509.

16. Singh, N.; Sangwan N. K.; Dhindsa, K. S. Pest. Manag.Sci. 2000, 56 (2), 284-288.

17. Rani, P.; Srivastava, V. K.; Kumar, A. Eur. J. Med. Chem. 2004, 39 (5), 449-452.

18. Lucey, N. M.; McElhinhey, R. S.; Hoshi, A.; Kimura, K.; Fujji, S.; Ogawa, M.; J. Chem. res. (S), 1985, 240.

19. Bodey, G. P.; Alberto, P. Eds. Elsevier Science, 1984.
20. Gadakh, A. V.; Pandit, C.; Rindhe, S.; Karale, B. K. Bio Med. Chem. Let. 2010, 20 (18), 5572-5576

21. Basser, M. A.; Jadhav, V. D.; Phule, R. M.; Archana, Y. V.; Vibhute, Y. B. Orient. J. Chem, 2000, 16, 553-556.

22. Dhokale, N. T.; Karale B. K.; Nagawade, A. V. Res. J. of Chem. Sci. 2014 1(NCCICR2014), 100-105.

23. Vogel's, Text book of practical organic Chemistry, $5^{\text {th }}$ edition, J. Wiley, New York, 2012.

24. Geary, W. J. Coord. Chem. Rev., 1971, 7, 81122.

25. Keeney, M. E.; Osseo-Asare, K. Polyhedron 1984, 3 (6), 641-649.

26. Percy, G. C.; Thornton, D.A. Inorg, 1971, 7(7), 599-604.

27. Bukhari, I. H.; Arif, M.; Akbar, J.; Khan, A. H. Pakistan J. Biol. Sci., 2005, 8 (4), 614-617.

28. Basavaraju, B.; BhojyaNaik H.S.; Prabhakasa, M. C. E-Journal Chem., 2007, 4(1), 39-45.

29. Hamrit, H.; Diebbar-sid, S.; Benali-Baitich, O.; Khan M. A.; Bouet, G. Synth Met-Org. Chem. 2000, 30 (10), 1835-1848.

30. Mohapatra, B. B.; Saraf, S. K. J. Ind. Chem. Soc. 2003, 80 (7), 696-699.

31. Mehta, B. H.; Swar, Y. A. Asian J. of Chem. 2001, 13 (3), 928-932.

32. Hussain, R.; Juneja, H. D. Int. J. Chem. Sci. 2009, 7 (2), 632-638.

33. Perez, C.; Pauli, M.; Bazerque, P. Acta. Biol. Med. Exp. 1990, 15, 113-115.

34. Kurtoglu, M.; Ispir, E.; Kurtoglu N.; Serin, S. Dyes Pigm. 2008, 77 (1), 75-80.

35. El-Tabl, A. S.; El-Saied, F.A.; Plass, W.; AlHakimi, A. N. S, Acta. A 2008, 71 (1) 90-99. 